https://www.moderntechno.de/index.php/meait/article/view/meait05-02-006

DOI: 10.30890/2567-5273.2018-05-02-006

\title{
УДК 347.254
}

\section{THE CORRELATION OF «THE RIGHT TO HOUSING» AND «HOUSING RIGHTS» DEFINITIONS TO THE LEGISLATION OF UKRAINE СООТНОШЕНИЕ ПОНЯТИЙ «ПРАВО НА ЖИЛЬЕ» И «ЖИЛИЩНЫЕ ПРАВА» ПО ЗАКОНОДАТЕЛЬСТВУ УКРАИНЫ}

Karmaza O.O. / Kapmaza A.A.

D.Sc (Law), prof. / d.ю.н., npopecop ORCID: 0000-0003-4895-5220

University of Modern Knowledge, Kyiv, 57/3 Vasylkivska str, 03022 Университет современных знаний, Киев, ул. Васильковская, 57/2, 03022

Abstract. The work carried out a scientific analysis of the concepts of "right to housing" and "housing rights". It has been established that "the right to housing" and "housing law" are different concepts. It is proved that the citizens' exercise of the constitutional right to housing takes place mainly in public law within the limits, in the manner and procedure established by law, and precedes the emergence, change or termination of residential rights, which are guaranteed by the rules of material and procedural private law, are protected and protected by the state.

Key words: housing, housing, housing law, housing legislation.

\section{Introduction.}

The rights of a natural person related to housing are guaranteed by the Constitution and are enshrined in the laws of Ukraine, included in the system of general human rights, and are the subject of scientific research, etc. Since civil rights are exercised and implemented around an object-housing, they can be conventionally grouped into a group of housing rights. United in this way, housing rights do not have particular features but are only a conditional combination of various rights around the object - housing. Such an association leads to the fact that the doctrine of social relations in relation to housing is considered as complex [1]. We believe that in case of realization by citizens enshrined in Article 47 of the Constitution, rights to housing within the limits provided to them by law, this gives rise to, change and termination of residential rights. Therefore, we agree with the scientists who consider "housing rights" and "the right to housing" as different concepts, and housing rights as derivatives from the constitutional right to housing.

\section{The main text.}

It should be noted that from the point of view of the theory of natural law, the right to housing is a natural and inalienable right without which a person can not exist in a society. This right is closely intertwined with the social economic policy of the state. Providing the state with proper conditions for the implementation of the right to housing and guaranteeing the inviolability of the law points to the level of development of democracy in the country. Ensuring the right to housing is carried out at the interstate and national levels. Thus, the Universal Declaration of Human Rights stipulates that everyone has the right to a standard of living, including housing, which is necessary to maintain the health and well-being of himself and his family (Article 25). The rules on the right to housing as part of the right to an adequate standard of living are contained in Article 11 of the International Covenant on Economic, Social and Cultural Rights. This right is proclaimed in the Convention for the Protection of 
Human Rights and Fundamental Freedoms and the European Social Charter. In addition, the right to housing is guaranteed by the constitutions of foreign states. For example: by the Constitution of Bulgaria (Article 33), Honduras (Article 178), Ecuador (Article 19), Estonia (Article 33), Spain (Article 47), Lithuania (Article 24), Macedonia (Article 26), Moldova (Article 29) , Germany (Article 13), Slovenia (Article 36), Russia (Article 40), Finland (Article 15 (a) (4)), Croatia (Article 34) etc.

The constitutional right to housing in Ukraine is enshrined in Section II "Rights, Freedoms and Responsibilities of a Person and Citizen", belonging to a person, a citizen, and not to state bodies or legal persons. The constitutional right to housing is not a "gift" from the state; it arises in a person from his birth, is inalienable, and terminates with the death. This right is closely linked to other human rights, such as the right to a family, to health care, to a safe environment, etc. Therefore, in practice, there are not surprising cases in which the obstacle to the creation or preservation of an existing family is the housing problem - the inability of citizens to realize the right to housing as a result of many factors, which, in particular, do not depend on the will of the person.

There is no unambiguous definition of "the constitutional right to housing" definition in legal science. In our opinion, in the broadest sense of the constitutional right to housing is a guarantee at the level of the Constitution, consolidation in legislative acts and the realization in practice of such conditions in which a person will have a sufficient standard of living for himself and his family, including gaining social or affordable housing, creation of proper and sufficient living conditions by the state that affect its physical, mental and social well-being, as well as his development as an individual in society. In the narrow sense, it is an opportunity for an individual to own or own a housing in accordance with the contract of hire (lease), use of housing and demand from obliged entities to ensure the realization of this right in full, as well as apply to the state authorities for protection and the restoration of their housing rights.

In the objective sense, the content of residential rights is reduced to a combination of general (constitutional) and specifically (sectoral) norms for satisfying a citizen's need for housing. Thus, objective housing law is a model of the possible behavior of subjects, and subjective housing law is a model of permissible or permissible behavior.

We draw attention to the fact that housing rights also have other features. Objective housing law is static and can not be in dynamics, whereas subjective housing law is from the moment of its occurrence in the state of implementation (dynamics). Thus, the fact that in the norms of objective housing law the possibility is transformed into reality by means of legal facts, voluntary acts of the subjects, and as a result, there arises subjective housing right.

The implementation of housing rights is possible to investigate: as acts established by law procedural actions (inaction) of the subject in a particular legal process, which are aimed at achieving the legal and actual result (for example, to solve the housing problem); as the "laid down" in the housing law the purpose - the acquisition of the right to housing. Having observed the legal nature of residential rights, we note that the implementation of subjective housing law is not the choice of 
a possible mode of behavior from the provided by a law the volume of opportunities (this is only part of the possibilities provided by the subjective right), but directly itself the behavior of a person, as a result of which the constitutional right to housing is implemented. Therefore, the choice of behavior within existing within the subjective right of authority, is a volitional decision of the subject.

At the same time, it should be noted that such a voluntary decision of the subject to implement housing rights shall be authorized by the state (proper form, procedure, content, content), based, in particular, on the principles of the rule of law, legality, etc. In case of non-compliance by the subject of housing relations, the algorithm of behavior (actions or inactivity) enshrined in the norms of law, in practice, will not achieve the goal (for example, the acquisition of ownership of housing). To date, there are not surprising cases when citizens violate the principle of law and implement the constitutional right to housing, in violation of the law, in particular, the notarization of a contract and state registration of the right to housing.

\section{Summary and Conclusions.}

The constitutional right to housing and housing rights are different legal categories. The realization of a person's rights in housing depends on the manner in which he has chosen the implementation of the constitutional right to housing and the rights and obligations conferred upon him by the contract or law. The implementation of housing rights must comply, in particular, with such principles as the guarantee of the implementation of housing rights, legality, freedom of choice, reasonableness, fairness, the inadmissibility of abuse of housing rights, etc.

The implementation of the constitutional right to housing takes place mainly in public law within the limits, in the manner and in accordance with the procedure established by law, and precedes the emergence, change or termination of residential rights, which are guaranteed by the rules of material and procedural law in private law, are protected, protected and restored by the state. The classification of residential rights can be made on the basis of different criteria: the division of the legal system; on a branch basis; by number of subjects; by subjects; the time of occurrence; on the grounds of occurrence, etc.

\section{References:}

1. Karmaza O.O. Kontseptsii okhorony ta zakhystu zhytlovykh prav u tsyvilistychnomu protsesi: avtoref. dys. ... d-ra yuryd. nauk. K. 2014. 36 s.

\section{Литература:}

1. Кармаза О.О. Концепції охорони та захисту житлових прав у цивілістичному процесі: автореф. дис. ... д-ра юрид. наук. К. 2014. 36 с.

Аннотация. В работе осуществлен научныцй анализ понятий «право на жилье» $u$ «жилищные права». Установлено, что «право на жилье» и «жилищное право» являются разными понятиями. Доказано, что осуществление гражданами конституционного права на жилье происходит преимущественно в публичном праве в пределах, способом и в порядке, установленные законом, и предшествует возникновению, изменению или прекращению жилищңных прав, обеспечиваемых нормами материального и процессуального частного права, которые охраняются и зашищаются государством.

Осуществление лицом жилищных прав зависит от выбранного им способа реализации 
конституциионного права на жилье и от предоставленных ему договором или законом пределов и ограничений этих прав. Осуществление жилищных прав должно отвечать, $в$ частности, таким принципам, как: гарантированность осуществления жилищных прав, законность, свобода воли, разумность, добросовестность, недопустимость злоупотребления жилыми правами и тому подобное.

Ключевые слова: жилье, право на жилье, жилищные права, жилищное законодательство.

Article sent: 11/09/2018 of 